is now based on scientific and orderly lines and has become just as much a part of science as engineering, chemistry and physics".

\section{Retirement of Prof. A. Morley Davies}

AFTER more than thirty years' service as demonstrator, lecturer and assistant professor, Dr. Arthur Morley Davies will shortly retire from the Department of Geology of the Imperial College of Science and Technology and readership in the University of London. Opportunity was taken by his colleagues in the Department to make him a presentation on Tuesday, June 25. Prof. Boswell recalled that Prof. Davies joined the College fifty-one years ago, and became a member of a stimulating group of students which included such well-known figures as $\mathrm{H}$. G. Wells, R. A. Gregory, A. T. Simmons, A. E. H. Tutton and A. V. Jennings. Tribute was paid to Prof. Davies for his long and devoted services to geology, to the College and to learned societies. The Royal Geographical Society conferred honorary fellowship on him, and the Geological Association honorary membership, as a mark of appreciation of his help and counsel during many years; and the Geological Society awarded him its Murchison Fund and, later, its Lyell Medal in recognition of his original work. Prof. Davies is the author of textbooks of geography, local geology, palæontology and, recently, of two volumes on the Tertiary faunas, which will long. remain a standard work of reference.

\section{Memorial to Sir Patrick Geddes}

THe Outlook Tower, standing on the Castle Hill, Edinburgh, was intended by the late Sir Patrick Geddes to express and exhibit stages of social development, using the history and geography of Edinburgh and Scotland as particular illustrations, and passing from them to the British Empire, the United States of America, Europe, and the world as a whole. The Tower was founded by him in 1892 as a type museum of geography, history and sociology and as a centre of civic and regional study; and it will always be associated with his name. There could be no more appropriate means of com. memorating Sir Patrick Geddes' work and influence than by establishing the Outlook Tower upon a permanent basis, and thus enable it further to be developed as an active centre for the dissemination of his ideas. With this end in view, a memorial, signed by a number of his friends and admirers, has been circulated, inviting contributions and asking also for the loan of any original letters or personal reminiscences, which with a considerable body of material already collected will be classified and edited so as to be available to students of civics and sociology. As Geddes was the apostle of town and regional planning, and devoted his life to promote intelligent and stimulating relationships between man and his environment, we hope that the response to the appeal now made will be ready and generous. Contributions should be sent to Sir Thomas B. Whitson, 21 Rutland Street, Edinburgh, and letters or other personal communications bearing upon Sir Patrick Geddes' life and work to the honorary secretary, Outlook Tower, Castlehill, Edinburgh.

\section{Gas-Storage of Fruit}

Frve coolers, specially made to complete the equipment of the experimental refrigerated chambers at the Ditton Laboratory of the Department of Scientific and Industrial Research, were presented to the Laboratory on July 5. Three of the coolers were given by Mr. S. W. Mount, of Patricksbourne, Canterbury, on behalf of a number of British fruitgrowers who are owners of gas-stores; the other two by Lord Dudley Gordon on behalf of Messrs. J. and E. Hall, Ltd., refrigerating engineers of Dartford, by whom the coolers were designed and made. Sir Frank Smith, Secretary of the Department of Scientific and Industrial Research, in accepting the gift on behalf of the Department, said that it indicated the confidence of those concerned in the fruitgrowing industry in the work of the Department.

IN the course of his remarks Sir Frank Smith said that English apples do not do so well in cold storage as those from some other parts of the world; they are liable to rapid wastage on removal from store as the direct result of exposure to the low temperature. Fortunately, the Department has been able to find a solution of this difficulty, namely, 'gasstorage'. At a temperature of $41^{\circ} \mathrm{F}$., with the oxygen in the atmosphere reduced to 10 per cent, and with the carbon dioxide raised proportionally to 10 per cent-a result which can be simply achieved by controlled ventilation in a gas-tight store-the Bramley's Seedling can be kept in first-rate condition for so long as twelve months. The first commercial gas-store in Great Britain was built by Mr. Mount in 1929 ; to-day there are some forty gas-stores in operation with a total capacity of about 400,000 bushels. Gas-storage as a method of preserving fresh fruit is only in its infancy. During the 1934-35 season, homegrown pears, of the variety Conference, were kept in gas-storage at the Ditton Laboratory for some months, with highly promising results. The Laboratory has also carried out preliminary experiments on the gas-storage of tomatoes, and again the results have been sufficiently promising to warrant development.

\section{Conference on Folk-Dancing}

A CONFERENCE on folk-dancing, which is being held in London on July 15-20 in connexion with an International Folk-Dance Festival, will afford an exceptionally favourable opportunity for the comparative study of this survival of European folk art and ritual. Students from all parts of Europe, it is stated in a preliminary announcement by a correspondent of The Times in the issue of July 6, will be present, and will discuss selected and especially significant dances still found among the peasantry of the remoter parts of Europe. These will be illustrated in many instances by dancers of the country of origin, who are attending the conference 